УДК 355.40:004.83

Сергій Станіславович Гаценко (кандидат технічних наук)

Костянтин Володимирович Пащенко

Юрій Анатолійович Свередюк

Максим Свгенійович Старищ

Національний університет оборони України імені Івана Черняховського, Київ, Україна

\title{
МОДЕЛЬ ПРОЦЕСУ ВИЗНАЧЕННЯ ЗАГРОЗ ВОЄННІЙ БЕЗПЕЦІ, ЯК СКЛАДОВОЇ НАЦІОНАЛЬНОЇ БЕЗПЕКИ ДЕРЖАВИ
}

Подї останніх декількох років показує, щчо в сучасних міждержавних відносинах роль військової сили набуває все більш вагомого значення. Для досягнення своїх иілей геополітичні гравиі все частіше вдаються до застосування військової сили або використовують інші інструменти зовнішнього впливу (економічні, енергетичні, політичні), щзо прямо чи опосередковано створюють загрозу національніи безпеці та ї̈ складовим, насамперед воєнній безпеці держсави (ВБД). Дедалі частіше зовнішні чинники впливу набувають мени прогнозованого та передбачуваного характеру, а, відтак, їх руйнівна сила зростає. У зв'язку з ичм актуальності набуває питання щуодо створення інструментів визначення рівня ВБД з метою своєчасного реагування держави на виклики $і$ загрози.

Комплексний аналіз світових наукових здобутків та поглядів на проблему оцінювання та прогнозування рівня ВБД дає змогу зробити висновок, ще ВБД є складовою національної безпеки та являє собою систему політико-правових, організаційних, воєнних та технічних заходів держави, спрямованих на забезпечення своєчасного виявлення, запобігання й нейтралізацію загроз (ризиків, викликів) національним інтересам, зокрема із застосуванням військової сили. У свою чергу, оцінку рівня ВБД можна подати як інтегральний показник здатності держави до своєчасного виявлення $i$ запобігання (нейтралізаиіі) викликів, ризиків та загроз за визначеними індикаторами.

Ключові слова: начіональна безпека держави, воєнна безпека держави, прогнозування, механізм визначення рівня загроз.

\section{Ветуп}

Постановка проблеми. В умовах збройної агресії Росії проти України у вітчизняних та закордонних наукових джерелах більше уваги приділяють вивченню питання ВБД як невід'ємної складової національної безпеки. Одним із пріоритетних завдань у цій сфері є пошук шляхів підвищення рівня ВБД $[1,6-10]$. Для його розв'язання необхідно дослідити складну систему воєнної безпеки держави в цілому та механізми іiі оцінки і прогнозування зокрема.

Аналіз останніх досліджень і публікацій. На основі комплексного аналізу світових наукових здобутків та поглядів на проблему оцінювання та прогнозування рівня ВБД можна зробити висновок, що ВБД є складовою національної безпеки та являє собою систему політико-правових, організаційних, воєнних та технічних заходів держави, спрямованих на забезпечення своєчасного виявлення, запобігання й нейтралізацію загроз (ризиків, викликів) національним інтересам, зокрема із застосуванням військової сили. У свою чергу, оцінку рівня ВБД можна подати як інтегральний показник здатності держави до своєчасного виявлення і запобігання (нейтралізації) викликів, ризиків та загроз за визначеними індикаторами [1,9].

Однак, у силу різних причин, невирішеним залишається завдання формалізації процесу визначення рівня воєнної безпеки 3 метою подальшої його автоматизації.

Мета статті. Розробка когнітивно-семантичної моделі системи воєнної безпеки держави для визначення векторного критерію оцінювання рівня ВБД 3 метою подальшого стійкого управління, визначення цінності і впливу вхідних параметрів на функціонування та вибір стратегії управління сектором безпеки і оборони держави.

\section{Виклад основного матеріалу дослідження}

Воєнній небезпеці, як соціально-політичному явищу і науковій категорії, суспільства і суверенної держави від зазіхань із застосуванням воєнної сили. Поняття протиставляється воєнна безпека як стан захищеності прав і свобод громадян, базових інтересів та цінностей воєнної безпеки тісно пов'язане 3 поняттям національної безпеки держави.

Однією 3 важливих в цьому плані була i залишається проблема вироблення i реалізації виваженої політики, яка має враховувати геополітичну ситуацію в Центральній Європі, базуватися на реальних економічних можливостях України, відповідати вимогам збереження її 
суверенітету й територіальної цілісності, ураховувати не лише свої національні інтереси, а й інтереси сусідніх держав, їх воєнний потенціал, можливість мирного розвитку.

Можна вважати, що воєнна політика розробляється переважно для формування військової сили, регулювання ії складу та рівня 3 метою стримування військового насильства, запобігання збройним зіткненням i ефективної реалізації національних інтересів у геополітичному просторі.

В умовах сьогодення виникають нові проблеми, які потребують розроблення нових моделей воєнно-політичних відносин як на регіональному рівні, так і на світовій арені, спрямовують воєнну політику на активну протидію агресивним, екстремістським силам, на недопущення воєнних конфліктів, зміцнення стабільності у регіоні та світі.

Застосовуючи системний підхід, ВБД можна розглядати як складну та ієрархічно розподілену відкриту динамічну систему, що являє собою сукупність індикаторів, на які впливають загрози (ризики, виклики) внутрішнього і зовнішнього характеру, а також засоби реагування (нейтралізації, запобігання) держави на ці загрози (ризики, виклики). ВБД, як складна динамічна система існує в зовнішньому середовищі (сукупності світових воєнно-політичних процесів), отримуючи від нього зовнішні впливи через вхідні параметри i, у свою чергу, впливаючи на зовнішнє середовище через вихідні параметри.

Вхідні параметри процесу, який розглядається, можна розділити на три групи:

сукупність існуючих (виявлених) загроз (ризиків, викликів) національним інтересам;

параметри управління (наявна нормативноправова база, що регламентує ВБД, або прийняті вольові рішення);

інші чинники - це параметри, які також впливають на процес, але їх кількісні (якісні) значення щодо системи оцінюють або як ймовірні, або взагалі не відомі (не виявлені на момент визначення рівня ВБД).

На сьогодні існує достатньо невелика кількість моделей та методів визначення рівня воєнної безпеки. Поряд 3 перевагами таких моделей їх спільними недоліками $\epsilon$ : неврахування впливу загроз на чинники воєнної безпеки (або на інтегроване нормоване значення рівня воєнної безпеки держави), а також порядку взаємодії чинників воєнної безпеки; неможливість оперативного налаштування моделі у разі появи додаткових чинників, що впливають на рівень ВБД. Крім того, жодна 3 перерахованих вище моделей (методів) не розкриває природу чинників ВБД.

Bce це вимагає зосередження уваги на подальшому дослідження цієї проблематики 3 метою створення оптимальної моделі визначення рівня ВБД. На нашу думку, побудову моделі визначення рівня воєнної безпеки необхідно здійснювати, виходячи зі змісту, структури та

\section{основних складових ВБД.}

На основі Стратегії національної безпеки України [4], Воєнної доктрини України [5], Законів України "Про основи національної безпеки України" [6], "Про оборону України" [7], "Про розвідку" [8], які регламентують основні положення ВБД як складової національної безпеки України, визначено основні індикатори, що впливають на ВБД, та причинно-наслідкові зв'язки між ними. Проаналізувавши [4, 5, 9, 10], ми вдосконалили деякі групи індикаторів і пропонуємо визначати рівень ВБД за такими групами індикаторів (таблиця 1).

Враховуючи зазначене, ВБД можна охарактеризувати як складну слабко структуровану систему (ССС) - таку, що відображає кількість, взаємодію та зв'язки неоднорідних чинників (у воєнній, економічній, політичній та інших сферах). В [1-3] показано, що в разі побудови моделі на основі когнітивних карт (зваженого та/або знакового орієнтованого графа; КК) визначають як основні індикатори (фактори), що впливають на систему в цілому, так і причинно-наслідкові зв'язки підсистем і часткових критеріїв.

Сутність запропонованого підходу полягає в дослідженні семантичної інформації про функціонування і розвиток ССС шляхом побудови когнітивної карти. Основним елементом карти є індикатори та причинно-наслідкові зв'язки між ними. КК можна уявити у вигляді зваженого графа, в якому вершинам співставлені індикатори, а ребрам - вагомість за тією чи іншою шкалою. таке:

Формальне представлення когнітивної карти

$$
G=\langle E, W\rangle
$$

де $E=\left\{e_{1}, e_{2}, \ldots, e_{n}\right\}$-множина індикаторів, $W$ - бінарне відношення на множині $E$, що задає зв'язки між ними.

Отже система, яку моделюємо, описується кінцевою множиною індикаторів і причиннонаслідкових зв'язків між ними. Під індикатором будемо розуміти значущу характеристику (змінну, параметр). Індикатори можна характеризувати як якісними, так і кількісними величинами. Також індикатори можуть приймати значення на деякій шкалі у межах встановлених обмежень.

Модель процесу визначення та прогнозу рівня ВБД матиме такий вигляд:

$$
G=\left\langle E, \quad E_{T}, \quad E_{C}, W, O, V_{N}, V_{T}, Y\right\rangle
$$

де $O$ - множина шкал, які використовують для введення значень індикаторів; $V_{N}-$ множина початкових значень індикаторів; $E_{T} \subset N-$ підмножина цільових індикаторів; $V_{T}$ - множина бажаних значень цільових індикаторів (мета); $E_{C} \subset E \quad-\quad$ підмножина індикаторів безпосереднього контролю; $Y$ - множина альтернатив, тобто впливів на індикатори безпосереднього контролю $E_{C}$. 
Система індикаторів, за якими оцінюють рівень воєнної безпеки України

\begin{tabular}{|c|c|c|}
\hline $\begin{array}{l}\text { № } \\
3 / \Pi\end{array}$ & $\begin{array}{c}\text { Інтегральний } \\
\text { показник рівня ВБД }\end{array}$ & Зміст індикатора \\
\hline 1. & $\begin{array}{l}\text { Політико- } \\
\text { дипломатичні } \\
\text { можливості країни }\end{array}$ & $\begin{array}{l}\text { 1.1. Рівень інтегрованості в систему колективної безпеки. } \\
\text { 1.2. Наявність військових союзників (поза договором про колективну } \\
\text { безпеку). } \\
\text { 1.3. Рівень співробітництва з державами, що межують з Україною та/або } \\
\text { та провідними світовими державами. }\end{array}$ \\
\hline 2. & $\begin{array}{l}\text { Стан збройних сил та } \\
\text { інших військових } \\
\text { формувань }\end{array}$ & $\begin{array}{l}\text { 2.1. Розмір оборонного бюджету. } \\
\text { 2.2. Чисельність 3С держави та інших військових формувань. } \\
\text { 2.3. Рівень оснащеності озброєнням та МТЗ військових формувань (якість та } \\
\text { кількість О та ВТ). } \\
\text { 2.4. Мобілізаційні можливості та рівень мобілізаційної підготовки. }\end{array}$ \\
\hline 3. & $\begin{array}{l}\text { Розвідувальні } \\
\text { можливості держави }\end{array}$ & $\begin{array}{l}\text { 3.1. Оснащеність добуваючих підрозділів (частин) ОВТ. } \\
\text { 3.2. Обсяг бюджету спеціальних служб держави. }\end{array}$ \\
\hline 4. & $\begin{array}{l}\text { Організаційна } \\
\text { здатність держави до } \\
\text { оборони }\end{array}$ & $\begin{array}{l}\text { 4.1. Рівень відповідності нормативно-правової бази з питань забезпечення } \\
\text { воєнної безпеки. } \\
\text { 4.2. Рівень відповідності організації воєнно-політичного і стратегічного } \\
\text { управління державою ії ЗС та іншим військовим формуванням. }\end{array}$ \\
\hline 5. & $\begin{array}{l}\text { Економічний } \\
\text { потенціал }\end{array}$ & $\begin{array}{l}\text { 5.1. Валовий внутрішній продукт. } \\
\text { 5.2. Рівень володіння природними ресурсами. } \\
\text { 5.3. Рівень розвитку ОПК. }\end{array}$ \\
\hline 6. & $\begin{array}{l}\text { Демографічний } \\
\text { потенціал }\end{array}$ & $\begin{array}{l}\text { 6.1. Загальна чисельність населення. } \\
\text { 6.2. Моральний дух нації. } \\
\text { 6.3. Рівень здоров’я генофонду держави. }\end{array}$ \\
\hline 7. & $\begin{array}{l}\text { Науково-технічний } \\
\text { потенціал }\end{array}$ & $\begin{array}{l}\text { 7.1. Рівень освіченості населення. } \\
\text { 7.2. Ступінь розвитку військової науки. } \\
\text { 7.3. Обсяг бюджету, що виділяється на наукові дослідження та освіту. }\end{array}$ \\
\hline 8. & \multicolumn{2}{|c|}{ Відношення щільності населення держави до площі території. } \\
\hline
\end{tabular}

На основі отриманих результатів розробляють КК оцінювання рівня ВБД (рис. 1). КК яК орієнтований граф використовують для якісного оцінювання впливу окремих вершин (індикаторів) на рівень ВБД або стійкість системи (значення векторного критерію).

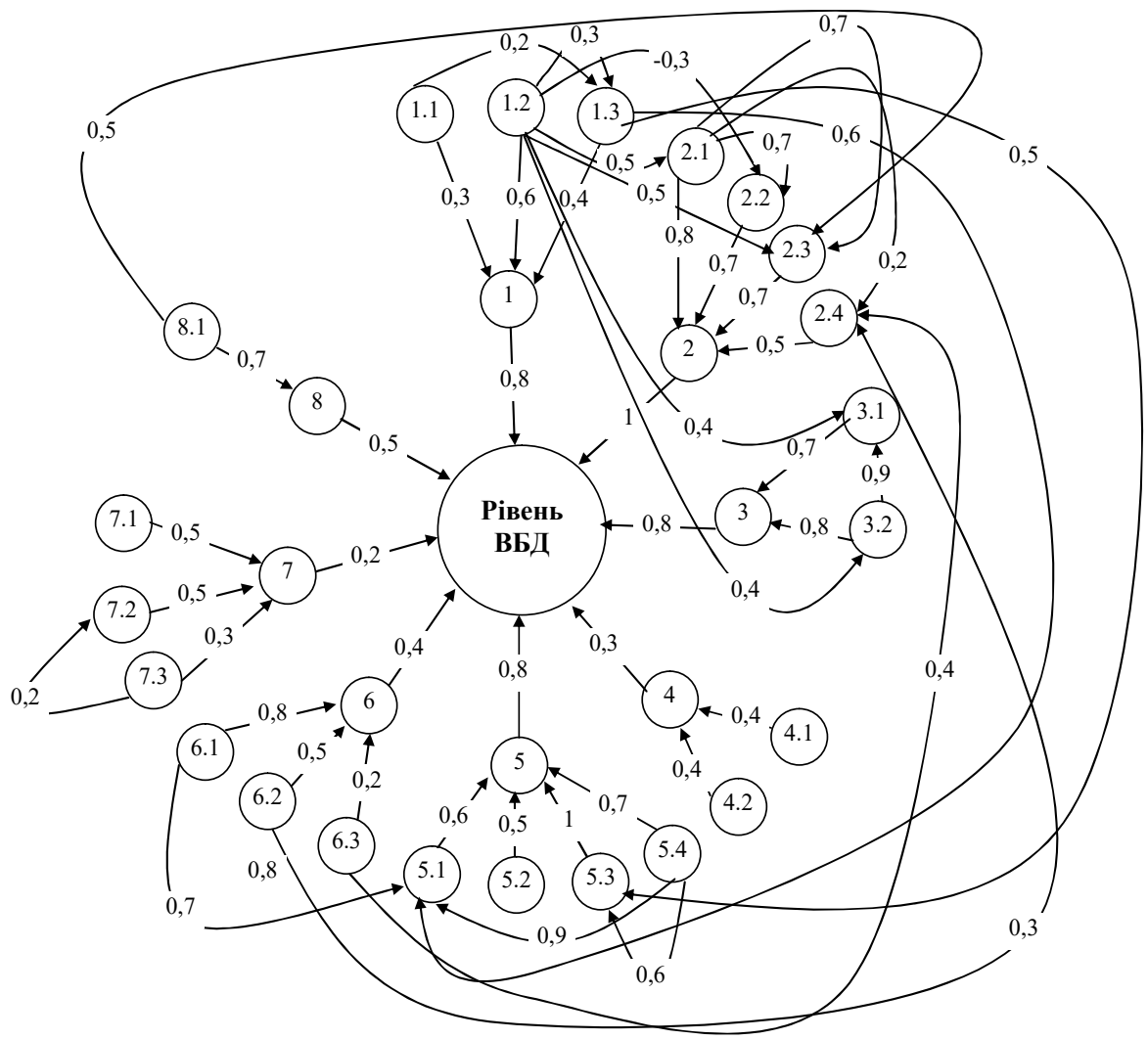

Рисунок 1. Когнітивна карта оцінювання рівня воєнної безпеки держави

На основі результатів аналізу КК (рис. 1) визначено, що всі обрані індикатори можуть бути 
використані як цільові. У свою чергу, за результатами аналізу зміни рівня ВБД як інтегрального показника, залежного від миттєвих значень індикаторів, можна спрогнозувати розвиток ситуації у різних умовах воєннополітичної обстановки.

Таким чином, можна зробити наступні висновки. Використання когнітивно-семантичного підходу для формування моделі визначення рівня воєнної безпеки держави дає змогу розробити оптимальну систему управління рівнем ВБД у складній ситуації за максимумом векторного критерію ефективності. Крім того, за допомогою запропонованого підходу усунено недоліки попередніх моделей - враховано взаємодію індикаторів (показників), а також ступінь впливу загроз на індикатори рівня ВБД.

Використовувати когнітивно-семантичний підхід i моделювання можна у складних i важкопрогнозованих ситуаціях достатньо оперативно, комплексно i системно охарактеризувати, обгрунтувати та на якісному рівні запропонувати способи розв'язання проблеми беручи до уваги індикатори воєнно-політичної обстановки.

КК як орієнтований граф використовують для якісного оцінювання впливу окремих вершин (індикаторів) на рівень ВБД або стійкість системи (значення векторного критерію).

За допомогою когнітивної карти можна визначити зміну рівня ВБД (стійкість системи), якщо деякі вершини (значення індикаторів) досить сильно впливатимуть на один або декілька індикаторів чи змінять знак дуги.

На основі результатів аналізу КК (рисунок 1) визначено, що всі обрані індикатори можуть бути використані як цільові. У свою чергу, за результатами аналізу зміни рівня ВБД як інтегрального показника, залежного від миттєвих значень індикаторів, можна спрогнозувати розвиток ситуації у різних умовах воєннополітичної обстановки. В таблиці 2 представлені результати розрахунків матриці покрокової зміни відносного рівня індикаторів воєнної безпеки держави.

Таблиця 2

Матриця суміжних переходів інтегрального показника "Рівень воєнної безпеки держави"

\begin{tabular}{|c|c|c|c|c|c|c|c|c|c|}
\hline \multirow{2}{*}{$\begin{array}{l}\text { Індикатори, за якими оцінюють } \\
\text { рівень воєнної безпеки України } \\
\text { (табл. 1) }\end{array}$} & \multicolumn{9}{|c|}{$\begin{array}{c}\text { Коефіцієнти впливу індикаторів на інтегральний показник "Рівень воєнної } \\
\text { безпеки держави” }\end{array}$} \\
\hline & 0 & 1 & 2 & 3 & 4 & 5 & 6 & 7 & 8 \\
\hline $\begin{array}{l}0 . \text { Рівень Воєнної безпеки } \\
\text { держави }\end{array}$ & 0 & 0,1 & 0,5 & 0,3 & 0,3 & 0,2 & 0,2 & 0,1 & 0,2 \\
\hline $\begin{array}{l}\text { 1. } \quad \text { Політико-дипломатичні } \\
\text { можливості країни }\end{array}$ & 0,1 & 0 & 0,2 & 0,3 & 0 & 0,1 & 0 & 0 & 0 \\
\hline $\begin{array}{l}\text { 2. Стан збройних сил та } \\
\text { інших військових формувань }\end{array}$ & 0,2 & 0 & 0 & 0,5 & 0,3 & 0,3 & 0,1 & 0,2 & 0,1 \\
\hline $\begin{array}{l}\text { 3. Розвідувальні можливості } \\
\text { держави }\end{array}$ & 0 & 0,1 & 0,1 & 0 & 0,1 & 0,2 & 0 & 0,1 & 0,1 \\
\hline $\begin{array}{l}\text { 4. Організаційна здатність } \\
\text { держави до оборони }\end{array}$ & 0 & 0 & 0 & 0,2 & 0 & 0,2 & 0,3 & 0,2 & 0,1 \\
\hline 5. Економічний потенціал & $-0,2$ & 0,1 & $-0,1$ & $-0,1$ & $-0,1$ & 0 & 0,2 & 0,2 & 0,2 \\
\hline 6. Демографічний потенціал & 0 & 0 & 0 & 0 & $-0,2$ & 0,1 & 0 & 0 & 0,1 \\
\hline $\begin{array}{l}7 . \quad \text { Науково-технічний } \\
\text { потенціал }\end{array}$ & 0 & 0,1 & 0 & 0,1 & 0 & 0,3 & 0 & 0 & 0 \\
\hline $\begin{array}{l}\text { 8. Відношення щільності } \\
\text { населення держави до площі } \\
\text { території }\end{array}$ & 0 & 0 & 0,1 & 0 & 0 & 0,2 & 0,6 & 0 & 0 \\
\hline
\end{tabular}

На рисунку 2 зображено графік рівня інтегрального показника "Рівень воєнної безпеки держави” відносно індикаторів, за якими оцінюють рівень воєнної безпеки України (таблиця 2).

Аналізуючи отримані результати, можна зробити висновок, що за такої ситуації буде відбуватись підвищення рівня ВБД. При цьому необхідно зауважити, що стрімке зростання триватиме протягом $6-7$ звітних періоди. Протягом послідуючих періодів очікується незначне підвищення. Разом 3 тим, критичними залишатимуться такі фактори як "Економічний потенціал”, “Науково-технічний потенціал”, “Демографічний потенціал”, “Розвідувальні можливості держави” та "Політико-дипломатичні можливості країни". 


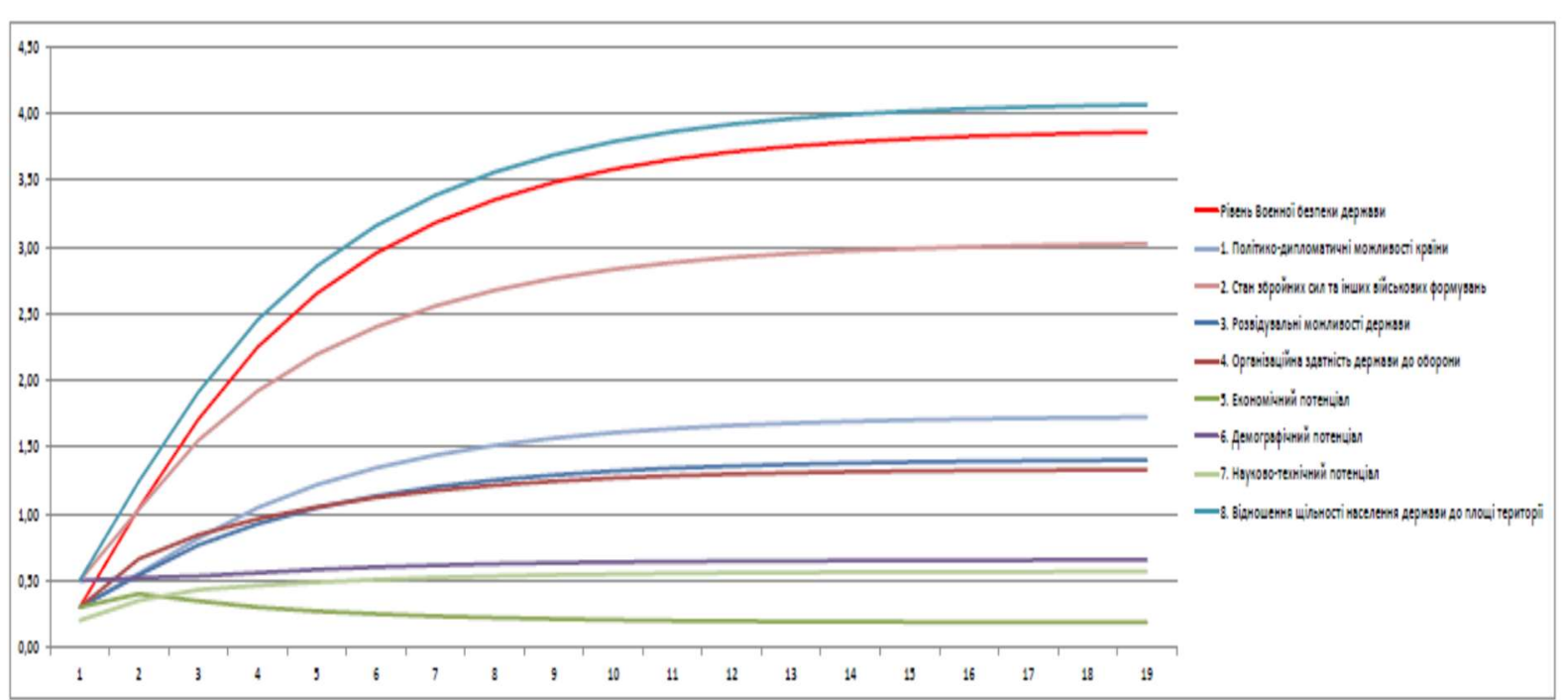

Рисунок 2. Графіки рівня інтегрального показника “Рівень воєнної безпеки держави” відносно індикаторів, за якими оцінюють рівень воєнної безпеки України

\section{Висновки і перспективи подальших досліджень}

Розрахунок вагових коефіцієнтів дуг когнітивної карти (орієнтованого графу) дасть можливість враховувати особливості функціонування системи воєнної безпеки держави та бажані напрями їі розвитку завдяки ранжуванню вершин за ступенем впливу на систему в цілому. Залежно від поставленого завдання, можна знайти оптимальну стратегію управління системою ВБД за максимумом векторного критерію ефективності.

\section{Лimepamypa}

1. Концептуальні засади розвитку системи забезпечення національної безпеки України : [аналіт. доп.] / Резнікова О.О., Цюкало В.Ю., Паливода В.О. та ін. - К. : НІСД 2015. - 58 с. 2. Гребенюк О. П. Застосування системнокогнітивного аналізу для автоматизації управління системою радіомоніторингу / О.П. Гребенюк, М. А. Роговець, В. А. Шуренок // Вісник ЖДТУ. - 2010. - №1 (52) - С.72-80. 3. Кузнецов О.П., Анализ влияний при управлении слабоструктурированными ситуациями на основе когнитивных карт. / Под ред. Н. А. Абрамовой, К. С. Гинсберга, Д. А. Новикова. - М. : КомКнига, 2006. - С. 313-344. 4. Указ президента України "Про рішення Ради національної безпеки i оборони України від 14 вересня 2020 року Про Стратегію національної безпеки України" [Електронний ресурс]. - Режим доступу: http//www.zakon3.rada.gov.ua. 5. Указ президента України № 555/2015 "Про рішення Ради національної безпеки і оборони України від 25 березня
Напрямки подальших досліджень 3 точки зору практичної реалізації $\epsilon$ розроблення методики системно-когнітивного моделювання i аналізу складних систем для отримання теоретичних i практичних знань про проблему і формулювання на цій основі практичних висновків. Моделювання базується на сценарному підході, що характеризують поточну ситуацію, бажаних цілей розвитку, комплексу заходів, що впливають на розвиток ситуації і системи параметрів (факторів), які спостерігаються та ілюструють поведінку процесів.

2021 року "Про нову редакцію Воєнної доктрини України" URL: http//www.president.gov.ua. 6. Закон України "Про основи національної безпеки України" від 21 червня 2019 р. № 2469-УІІІ [Електронний ресурс]. Режим доступу: http//www.portal.rada.gov.ua. 7. Про оборону України: Закон України № 1702-IX від 16 липня 2021 року № 1932-ХІІ (редакція станом на 05.05.2015) // Відомості Верховної Ради. - 1992. - № 9. - Ст. 106. 8. Про розвідку: Закон України № 808-IX від 17 липня 2020 року // Відомості Верховної Ради. 9. Шкідченко В.П. Елементи теорії воєнної безпеки : монографія / В.П.Шкідченко, В.Д. Кохно. - К.: БФ “Миротворець”, 2001. - 194 с. 10. Основи стратегії національної безпеки та оборони держави : підруч. / [О.П.Дузь-Крятченко, Ю.В.Пунда, В.П.Грищенко та ін.] ; за заг. ред. В.М. Телелима. - 3-е вид., перероб. І доп. - К. : НУОУ ім. Івана Черняховського, 2015. - 620 с.

\section{МОДЕЛЬ ПРОЦЕССА ОПРЕДЕЛЕНИЯ УГРОЗ ВОЕННОЙ БЕЗОПАСНОСТИ, КАК СОСТАВЛЕННОЙ НАЦОНАЛЬНОЙ БЕЗОПАСНОСТИ ГОСУДАРСТВА}

Сергей Станиславович Гаценко (кандидат технических наук)

Костянтин Володимирович Пащенко

Юрій Анатолійович Свередюк

Максим Свгенійович Старии

\section{Национальный университет обороны Украины имени Ивана Черняховского, Киев, Украина}


События последних нескольких лет показывает, что в современных межгосударственных отношениях роль военной силь приобретает все более весомое значение. Для достижения своих иелей геополитические игроки все чаще прибегают к применению военной силь или используют другие инструменты внешнего влияния (экономические, энергетические, политические), прямо или косвенно создающие угрозу национальной безопасности и ее составляющей, прежде всего военной безопасности государства (ВБД). Все чаще внешние факторы влияния приобретают менее прогнозируемый и предполагаемый характер, а, следовательно, их разрушительная сила растет. В связи с этим актуальность приобретает вопрос создания инструментов определения уровня ВБД с иелью своевременного реагирования государства на вызовы и угрозы.

Комплексный анализ мировых научных достижений и взглядов на проблему оценки и прогнозирования уровня ВБД позволяет сделать вывод, что ВБД является составной частью национальной безопасности и представляет собой систему политико-правовых, организационных, военных и технических мероприятий государства, направленных на обеспечение своевременного выявления, предотвращения и нейтрализации угроз (рисков, вызовов) нацииональным интересам, в том числе с применением военной силь. В свою очередь, оценку уровня ВБД можно представить как интегральный показатель способности государства к своевременному выявлению и предотвращению (нейтрализачии) вызовов, рисков и угроз по определенным индикаторам.

Ключевые слова: национальная безопасность государства, военная безопасность государства, прогнозирование, механизм определения уровня угроз.

\title{
MODEL OF THE PROCESS OF DETERMINING THREATS TO MILITARY SECURITY AS A COMPONENT OF NATIONAL SECURITY OF THE STATE
}

\author{
Serhii Hatsenko (Candidate of technical sciences) \\ Kostyantin Pashchenko \\ Yurij Sveredyuk \\ Maksim Starish
}

\section{National Defence University of Ukraine named after Ivan Cherniakhovskyi, Kyiv, Ukraine}

The events of the last few years show that in modern interstate relations the role of military force is becoming increasingly important. To achieve their goals, geopolitical players increasingly resort to the use of military force or use other instruments of external influence (economic, energy, political), which directly or indirectly pose a threat to national security and its components, especially military security (WBD). Increasingly, external influences are becoming less predictable and predictable, and, consequently, their destructive power is growing. In this regard, the question of creating tools for determining the level of WBD in order to respond to the state in a timely manner to challenges and threats becomes relevant.

A comprehensive analysis of world scientific achievements and views on the problem of assessing and forecasting the level of WBD allows us to conclude that WBD is a component of national security and is a system of political, legal, organizational, military and technical measures of the state to ensure timely detection, prevention and neutralization. threats (risks, challenges) to national interests, in particular with the use of military force. In turn, the assessment of the level of WBD can be presented as an integral indicator of the state's ability to timely identify and prevent (neutralize) challenges, risks and threats according to certain indicators.

Key words: national security of the state, military security of the state, forecasting, the mechanism of definition of level of threats.

\section{References}

1. Kontseptualni zasady rozvytku systemy zabezpechennia natsionalnoi bezpeky Ukrainy : [analit. dop.] / Reznikova O.O., Tsiukalo V.Iu., Palyvoda V.O. ta in. - K. : NISD, 2015. - 58 s. 2. Hrebeniuk O. P. Zastosuvannia systemnokohnityvnoho analizu dlia avtomatyzatsii upravlinnia systemoiu radiomonitorynhu / O.P. Hrebeniuk, M. A. Rohovets, V. A. Shurenok // Visnyk ZhDTU. - 2010. - №1 (52) - S.72-80. 3. Kuznetsov O.P., Analyz vlyianyi pry upravlenyy slabostrukturyrovannыmy sytuatsyiamy na osnove kohnytyvnыkh kart. / Pod red. N. A. Abramovoi, K. S. Hynsberha, D. A. Novykova. - M. : KomKnyha, 2006. S. 313-344. 4. Ukaz prezydenta Ukrainy "Pro rishennia Rady natsionalnoi bezpeky i oborony Ukrainy vid 14 veresnia 2020 roku Pro Stratehiiu natsionalnoi bezpeky Ukrainy" [Elektronnyi resurs]. - Rezhym dostupu: http//www.zakon3.rada.gov.ua. 5. Ukaz prezydenta Ukrainy № 555/2015 "Pro rishennia Rady natsionalnoi bezpeky i oborony Ukrainy vid 25 bereznia 2021 roku "Pro novu redaktsiiu Voiennoi doktryny Ukrainy" [Elektronnyi resurs]. - Rezhym dostupu: http//www.president.gov.ua. 6. Zakon Ukrainy "Pro osnovy natsionalnoi bezpeky Ukrainy" vid 21 chervnia 2019 r. № 2469-UIII URL: http//www.portal.rada.gov.ua. 7. Pro oboronu Ukrainy: Zakon Ukrainy № 1702-IKh vid 16 lypnia 2021 roku № 1932-KhII (redaktsiia stanom na 05.05.2015) // Vidomosti Verkhovnoi Rady. - 1992. - № 9. - St. 106. 8. Pro rozvidku: Zakon Ukrainy № 808-IKh vid 17 lypnia 2020 roku // Vidomosti Verkhovnoi Rady. 9. Shkidchenko V.P. Elementy teorii voiennoi bezpeky : monohrafiia / V.P.Shkidchenko, V.D. Kokhno. - K.: BF "Myrotvorets", 2001. - 194 s. 10. Osnovy stratehii natsionalnoi bezpeky ta oborony derzhavy : pidruch. / [O.P.Duz-Kriatchenko, Yu.V.Punda, V.P.Hryshchenko ta in.] ; za zah. red. V.M. Telelyma. - 3-e vyd., pererob. I dop. - K. : NUOU im. Ivana Cherniakhovskoho, 2015. - 620 s. 